\title{
Do standardization and quantification of histopathological criteria improve the diagnosis of inflammatory bowel disease?
}

\author{
Padronização e quantificação de critérios histopatológicos \\ melhoram o diagnóstico da doença intestinal inflamatória?
}

Rosimeri Kuhl Svoboda Baldin'; José Ederaldo Queiroz Telles²; Renato Araújo Bonardi³;

Heda Maria Barska dos Santos Amarante ${ }^{4}$; Antônio Baldin Júnior ${ }^{5}$

\begin{abstract}
Introduction: Inflammatory bowel disease comprises two major categories: Crohn's disease and ulcerative rectocolitis, both with different clinical and histological aspects, causing sometimes significant morbidity. Objectives: Choose and apply standardized and quantified histopathological diagnosis method, and compare the results and quality index with the original diagnosis. Materials and methods: 43 histological colonoscopic biopsies of 37 patients were re-evaluated by standardized system. Results and discussion: The original diagnoses were more inconclusive (23.3\%) than those standardized (2.3\%). The agreement with gold standard (clinical, colonoscopical, and radiological diagnosis) was higher on standardized diagnoses (95.3\%) than in original (74.4\%), especially in relation to Crohn's disease, which percentages were $92.3 \%$ and $46.1 \%$, respectively. The quality index was calculated in conclusive diagnosis of each method. For ulcerative rectocolitis, both methods showed sensitivity and negative predictive value of $100 \%$; otherwise the original diagnosis demonstrated specificity of $85.7 \%$, positive predictive value of $96.3 \%$ and accuracy of $97.0 \%$, and the standardized diagnosis $92.3 \%, 96.7 \%$ and $97.6 \%$, respectively. For Crohn's disease, there is specificity and positive predictive value of $100 \%$ in both methods; the original diagnosis showed sensitivity of $85.7 \%$, negative predictive value of $96.3 \%$ and accuracy of $97 \%$, while for the standardized diagnoses $92.3 \%, 96.7 \%$, and $97.6 \%$, respectively. Conclusion: The standardized diagnosis presented a higher percentage of correct and conclusive diagnoses than those presented in the original diagnosis, especially for Crohn's disease, as well as equal or slightly higher values in some quality index.
\end{abstract}

Key words: ulcerative rectocolitis; Crohn's disease; biopsy; pathology.

\section{INTRODUCTION}

Inflammatory bowel disease (IBD) is the generic term for a specific group of chronic inflammatory disorders of unknown origin affecting the gastrointestinal tract, with outbreaks of acute exacerbation ${ }^{(10)}$. For not presenting specific pathognomonic signs the diagnosis is made by the correlation of clinical symptoms with various signals detected on endoscopic, radiological and histopathological findings, which are add together to a more specific conclusion. Colonoscopy is essential to make possible the diagnosis and evaluate the extent, severity and distribution of IBD. Information obtained at colonoscopy, associated histopathological criteria, providing data for classify IBD in one of its two major subgroups: ulcerative rectocolitis (UC) and Crohn's disease (CD).

First submission on 25/09/13; last submission on 05/03/14; accepted for publication on 27/03/14; published on 20/06/14

1. Master of Science in Microbiology, Parasitology and Pathology at Universidade Federal do Paraná (UFPR); pathologist at Hospital de Clínicas at UFPR; assistant professor at UFPR-Medical Pathology Department.

2. Doctor in Therapeutic and Internal Medicine at Universidade Federal de São Paulo (UNIFESP); pathologist at Hospital de Clínicas (UFPR); adjunct professor at UFPR-Medical Pathology Department.

3. Doctor in Surgery at UFPR; head of Department of Surgery of UFPR.

4. Master of Medicine by UFPR; assistant professor at UFPR-Internal Medicine Department.

5. Master of Science in Microbiology, Parasitology and Pathology at UFPR; surgeon at Hospital de Clínicas at UFPR. 
About $10 \%-20 \%$ of cases are designated as indeterminate IBD, which diagnosis cannot be defined as UC or $\mathrm{CD}^{(8)}$. The specific diagnosis is important to evaluate surgical treatment as well as long-term follow up since the UC and DC medical management is different as regards the evolution of the disease and the indication for surgery. The relative risk of colorectal cancer is highest in patients with IBD than in the general population ${ }^{(5,7)}$.

\section{OBJECTIVES}

Choose and apply standardized and quantified histopathological diagnosis method, and compare the results and quality index with the original diagnosis.

\section{MATERIALS AND METHODS}

This study was approved by the Research Ethics Committee at Hospital de Clínicas-Universidade Federal do Paraná (UFPR), under protocol number: 718.137/2003-09, and was recorded in Research Database System at UFPR (BANPESQ) under code number: 2003005726. Retrospective study was performed on IBD of 255 outpatient registers at Hospital de Clínicas at UFPR, in July 2004. There were 130 patients diagnosed with CD and 125 UC. We found 445 histopathological examinations, colonic endoscopic biopsies of these patients in files of Department of Pathology. Among these, only 43 examinations of 37 patients had all the inclusion criteria (some had made more than one exam that met the inclusion criteria). Each test consisted of a series of 5-8 slides, and each slide assembly (relative to one exam) there was 9-39 fragments of bowel mucosa. All these material totaled 264 slides and 846 fragments. For sample selection we established the following criteria: 1) patients with active colitis at the time of biopsy; 2) clinical diagnosis established; 3) clinical segment of at least 12 months; 4) at least five different samples of the colon, one of which necessarily rectum. The material was previously set in aqueous 10\% formalin and submitted for processing. The capsules were placed in an automatic tissue processor, which held dehydration, diaphanization, impregnation, and embedment in paraffin. The specimens were included in paraffin for holding samples microtome cuts of $4-5 \mathrm{~mm}$. The material was stained with hematoxylin-eosin (HE) and examined under light microscopy ${ }^{(2,19,22)}$. For histopathological evaluation, the method developed by Tanaka et al. ${ }^{(25)}$ was chosen. It was reproduced in Table $\mathbf{1}$ and $\mathbf{2}$ just like elaborated by the authors. The data in these tables defined criteria $\mathrm{H} 1$ to $\mathrm{H} 9$, which were marked as present (1) or absent (0). From these values were made the calculations to IBD and $\mathrm{CD}$, which scores were used to classify the cases into the categories described in Table 1 and 2. The original histopathological diagnoses of 37 patients included in this study (43 exams) were classified as UC or CD when these hypotheses were suggested or indicated compatibility with them, and classified as inconclusive when these possibilities were not expected.

TABLE 1 - Simple criteria for differentiate IBD and other forms of colitis (non IBD)

\begin{tabular}{lll}
\hline Category & Definition & SCORE IBD $\left(\mathrm{S}_{\mathrm{IBD}}\right)=2 \mathrm{H}_{1}+3 \mathrm{H}_{2}+3 \mathrm{H}_{3}+2 \mathrm{H}_{4}-4$ \\
\hline Definite IBD & $\mathrm{S}_{\mathrm{IBD}} \geq 2$ & $\mathrm{H}_{1}$ : Cryptic atrophy \\
Probable IBD & $\mathrm{S}_{\mathrm{IBD}}=1$ & $\mathrm{H}_{2}$ : Cryptic distortion \\
Unknown & $\mathrm{S}_{\mathrm{IBD}}=0$ & $\mathrm{H}_{3}$ : Basal plasmacytosis with intense MMNII \\
Probable non-IBD & $\mathrm{S}_{\mathrm{IBD}}=-1$ & $\begin{array}{l}\mathrm{H}_{4} \text { : Paneth cells metaplasia distal to the right } \\
\text { angle of the colon }\end{array}$ \\
Definite non-IBD & $\mathrm{S}_{\mathrm{IBD}} \leq-2$ &
\end{tabular}

Source: Tanaka et al. ${ }^{(25)}$.

IBD: inflammatory bowel disease; MMNII: monomorfonuclear inflammatory infiltrate.

TABLE 2 - Simple criteria for differentiate CD and UC

\begin{tabular}{|c|c|c|}
\hline Category & Definition & $\begin{array}{l}\text { Score } \mathrm{CD}\left(\mathrm{S}_{\mathrm{CD}}\right)=2 \mathrm{H}_{5}+3 \mathrm{H}_{6} \\
\quad+2 \mathrm{H}_{7}+3 \mathrm{H}_{8}-3 \mathrm{H}_{9}-5\end{array}$ \\
\hline Definite CD & $1.0 \leq \mathrm{S}_{\mathrm{CD}}$ or $\mathrm{EG}$ & $\begin{array}{l}\mathrm{H}_{5} \text { : Segmental distribution of atrophy and } \\
\text { crypt distortion }\end{array}$ \\
\hline Probable CD & $0.3 \leq \mathrm{S}_{\mathrm{CD}}<1.0$ & $\mathrm{H}_{6}$ : Segmental distribution of mucin depletion \\
\hline Underteminate & $-0.3<\mathrm{S}_{\mathrm{CD}}<0.3$ & $\begin{array}{l}\mathrm{H}_{7} \text { : Preservation of mucin at the edges of } \\
\text { ulcers or crypts surrounded by neutrophils }\end{array}$ \\
\hline Probable UC & $-1.0<\mathrm{S}_{\mathrm{CD}} \leq 0.3$ & $\begin{array}{l}\mathrm{H}_{8} \text { : Division of NB* with MMNII focal by NB* } \\
\text { with MMNII }\end{array}$ \\
\hline Definite UC & $\mathrm{S}_{\mathrm{CD}} \leq-1.0$ & $\begin{array}{l}\mathrm{H}_{9} \text { : Division of } \mathrm{NB}^{*} \text { with cryptic atrophy and } \\
\text { severe MMNII by NB* with severe MMNII }\end{array}$ \\
\hline
\end{tabular}

Source: Tanaka et al. ${ }^{(25)}$.

CD: Crohn's disease; UC: ulcerative colitis; EG: epithelioid granuloma; $N B^{*}$ : number of biopsies; MMNII: monomorfonuclear inflammatory infiltrate.

\section{RESULTS}

We selected 253 patients - 107 men (42\%) and 146 women (58\%) - from IBD outpatient, classified into 129 UC (51.0\%) and $124 \mathrm{CD}(49.0 \%)$, which had a total of 445 subjected to histopathological colon biopsies examination, with an average of 1.7 per patient. After surveying the results of 445 biopsies, only $43(9.6 \%)$ met the inclusion criteria for the present study. Table 3 shows clinical data and diagnosis based on gold standard, diagnosis reported during request, the histopathological original diagnosis (OD) and reviewed standardized diagnoses (RSD), if granulomas are present 
TABLE 3 - Main clinical and histopathological data from analyzed exams ( 43 exams of 37 patients)

\begin{tabular}{|c|c|c|c|c|c|c|c|c|c|}
\hline Exam & Age & Gender & $\begin{array}{l}\text { Follow } \\
\text { (years) }\end{array}$ & $\begin{array}{c}\text { Gold standard } \\
\text { clinical diagnosis }\end{array}$ & $\begin{array}{l}\text { Hypothesis on } \\
\text { request exam }\end{array}$ & OD & RSD & $\begin{array}{c}\text { Presence of } \\
\text { granuloma in OD }\end{array}$ & $\begin{array}{c}\text { Presence of } \\
\text { granuloma in RSD }\end{array}$ \\
\hline 1 & 15 & M & 6 & $\mathrm{CD}$ & $\mathrm{CD}$ & Inconclusive & $\mathrm{CD}$ & No & No \\
\hline 2 & 27 & $\mathrm{~F}$ & 8 & UC & UC & Inconclusive & UC & No & No \\
\hline 3 & 26 & $\mathrm{~F}$ & 5 & UC & UC & UC & UC & No & No \\
\hline 4 & 26 & $\mathrm{~F}$ & 5 & UC & UC & UC & UC & No & No \\
\hline 5 & 22 & M & 3 & $\mathrm{CD}$ & $\mathrm{CD}$ & Inconclusive & $\mathrm{CD}$ & Yes & Yes \\
\hline 6 & 19 & $\mathrm{~F}$ & 6 & UC & UC & UC & UC & No & No \\
\hline 7 & 30 & $\mathrm{~F}$ & 9 & UC & UC & $\mathrm{UC}$ & UC & No & No \\
\hline 8 & 30 & $\mathrm{~F}$ & 2 & UC & UC & UC & UC & No & No \\
\hline 9 & 41 & M & 1 & $\mathrm{CD}$ & $\mathrm{CD}$ & Inconclusive & $\mathrm{CD}$ & No & Yes \\
\hline 10 & 45 & $\mathrm{~F}$ & 21 & UC & UC & UC & UC & No & No \\
\hline 11 & 20 & $\mathrm{~F}$ & 3 & $\mathrm{UC}$ & UC & UC & UC & No & No \\
\hline 12 & 27 & M & 1 & UC & UC & UC & UC & No & No \\
\hline 13 & 25 & $\mathrm{~F}$ & 2 & $\mathrm{UC}$ & UC & UC & UC & No & No \\
\hline 14 & 24 & M & 1 & UC & UC & UC & UC & No & No \\
\hline 15 & 32 & M & 17 & UC & UC & UC & UC & No & No \\
\hline 16 & 36 & $\mathrm{~F}$ & 11 & UC & UC & UC & UC & No & No \\
\hline 17 & 31 & $\mathrm{~F}$ & 4 & UC & UC & UC & UC & No & No \\
\hline 18 & 47 & M & 14 & UC & UC & UC & UC & No & No \\
\hline 19 & 50 & $\mathrm{~F}$ & 13 & $\mathrm{UC}$ & UC & Inconclusive & UC & No & No \\
\hline 20 & 29 & M & 5 & $\mathrm{UC}$ & UC & UC & UC & No & No \\
\hline 21 & 30 & $\mathrm{~F}$ & 6 & UC & UC & UC & UC & No & No \\
\hline 22 & 41 & $\mathrm{~F}$ & 5 & $\mathrm{CD}$ & $\mathrm{CD}$ & $\mathrm{CD}$ & $\mathrm{CD}$ & Yes & Yes \\
\hline 23 & 50 & $\mathrm{~F}$ & 13 & UC & UC & Inconclusive & UC & No & No \\
\hline 24 & 15 & M & 6 & $\mathrm{CD}$ & None & CD & $\mathrm{CD}$ & Yes & Yes \\
\hline 25 & 37 & $\mathrm{~F}$ & 8 & $\mathrm{CD}$ & $\mathrm{CD}$ & Inconclusive & UC & No & No \\
\hline 26 & 36 & M & 7 & $\mathrm{CD}$ & $\mathrm{CD}$ & Inconclusive & $\mathrm{CD}$ & No & No \\
\hline 27 & 41 & $\mathrm{~F}$ & 11 & $\mathrm{UC}$ & UC & UC & UC & No & No \\
\hline 28 & 14 & M & 5 & $\mathrm{CD}$ & $\mathrm{CD}$ & $\mathrm{CD}$ & $\mathrm{CD}$ & Yes & Yes \\
\hline 29 & 17 & $\mathrm{~F}$ & 5 & UC & UC & UC & UC & No & No \\
\hline 30 & 15 & M & 5 & $\mathrm{CD}$ & $\mathrm{CD}$ & UC & $\mathrm{CD}$ & No & Yes \\
\hline 31 & 27 & $\mathrm{~F}$ & 7 & UC & UC & UC & UC & No & No \\
\hline 32 & 23 & M & 8 & $\mathrm{CD}$ & $\mathrm{CD}$ & Inconclusive & $\mathrm{CD}$ & No & Yes \\
\hline 33 & 22 & $\mathrm{~F}$ & 5 & UC & UC & UC & UC & No & No \\
\hline 34 & 37 & M & 9 & UC & UC & UC & Inconclusive & No & No \\
\hline 35 & 20 & M & 9 & $\mathrm{CD}$ & $\mathrm{CD}$ & $\mathrm{CD}$ & $\mathrm{CD}$ & No & Yes \\
\hline 36 & 36 & $\mathrm{~F}$ & 6 & $\mathrm{CD}$ & $\mathrm{CD}$ & $\mathrm{CD}$ & $\mathrm{CD}$ & Yes & Yes \\
\hline 37 & 57 & $\mathrm{~F}$ & 4 & $\mathrm{CD}$ & $\mathrm{CD}$ & $\mathrm{CD}$ & $\mathrm{CD}$ & Yes & Yes \\
\hline 38 & 23 & $\mathrm{~F}$ & 8 & UC & UC & UC & UC & No & No \\
\hline 39 & 15 & $\mathrm{~F}$ & 13 & UC & UC & Inconclusive & UC & No & No \\
\hline 40 & 23 & M & 5 & UC & UC & UC & UC & No & No \\
\hline 41 & 43 & M & 14 & UC & UC & $\mathrm{UC}$ & UC & No & No \\
\hline 42 & 42 & M & 10 & UC & $\mathrm{CD}$ & UC & UC & No & No \\
\hline 43 & 44 & M & 14 & UC & UC & UC & UC & No & No \\
\hline Average & 25 & - & 6 & - & - & - & - & - & - \\
\hline Total & - & - & - & - & - & - & - & $6(46.1 \%)$ & $10(76.9 \%)$ \\
\hline
\end{tabular}


All RSD were classified as definite for one out of the two diseases (CD or UC), except for case 34 that was classified as inconclusive. These 43 exams were discriminated in 30 (69.8\%) UC diagnoses, and 13 (30.2\%) CD diagnoses. 37 patients presented 43 exams, which were categorized in 25 (67.6\%) UC and $12(32.4 \%) \mathrm{CD}$ (there was more than one examination for the same patient included in the study). From these 37 patients, 16 (43.2\%) were male, and 21 (56.8\%) female. From 25 patients with UC, 8 (32.0\%) were male, and 17 (68.0\%) female. From the 12 individuals with CD, 8 (66.7\%) were male, and 4 (33.3\%) female. Patients were diagnosed with IBD at $4-57$ years of age, mean 25 years $\pm 10,1$. The comparison between OD and RSD regarding the percentage of exams with conclusive and inconclusive diagnoses is presented in Table 4. To compare OD and RSD results in percentages of assertiveness and conclusiveness of diagnosis, binomial test was applied, since each sample was evaluated by two diagnostic methods (OD and RSD), determining the result classified into two categories. Values of $p<0.05$ were considered statistically significant. The binomial test results indicated rejection of the null hypothesis at a significance level of 5\% ( $\phi=0.0117)$, this allows us to affirm that there is a statistically significant difference between OD and RSD in relation to the percentage of exams with inconclusive diagnoses. Table 4 shows that the percentage of tests considered inconclusive by OD (23.3\%) is higher than the well regarded by RSD (2.3\%). The assessment of the proportion of cases with correct diagnosis by OD and RSD for each disease (UC and CD) is presented in Table 5. For UC, the test result indicated the non-rejection of the null hypothesis at a significance level of $5 \%(p=0.1250)$. Thus, it can be stated that there is no statistically significant difference between OD and RSD in relation to the percentage of samples with correct diagnoses for UC. For $\mathrm{CD}$, the test result indicated rejection of the null hypothesis at a significance level of $5 \%(p=0.0313)$. Thus, it can be stated that there is a statistically significant difference between OD and RSD in relation to the percentage of samples with correct diagnoses for $\mathrm{CD}$. Table 5 shows that the percentage of correct cases by RSD (92.3\%) is higher than the percentage for OD (46.1\%). The results of the quality rates for the conclusive diagnoses obtained by OD and RSD are shown in Table 6.

TABLE 4 - Distribution of diagnosis as conclusive or inconclusive ( $n=43$ exams)

\begin{tabular}{ccc}
\hline Diagnosis & OD & RSD \\
\hline Conclusive & $33(76.7 \%)$ & $42(97.7 \%)$ \\
Inconclusive & $10(23.3 \%)$ & $1(2.3 \%)$ \\
Total (exams) & 43 & 43 \\
\hline
\end{tabular}

OD: original diagnosis; RSD: reviewed standardized diagnosis.
TABLE 5 - Comparison of OD and RSD in relation to the percentage of cases with correct diagnosis of UC and CD

\begin{tabular}{lcc|cc}
\hline \multirow{2}{*}{ Diagnosis } & \multicolumn{4}{c}{ Gold standard } \\
\cline { 2 - 5 } & OD & RSD & OD & RSD \\
\cline { 2 - 5 } & $26(86.7 \%)$ & $29(96.6 \%)$ & $6(46.1 \%)$ & $12(92.3 \%)$ \\
\hline Correct & $4(13.3 \%)$ & $1(3.3 \%)$ & $7(53.8 \%)$ & $1(7.7 \%)$ \\
Incorrect $(*)$ & 30 & 30 & 13 & 13 \\
Total & &
\end{tabular}

OD: original diagnosis; RSD: reviewed standardized diagnosis; UC: ulcerative colitis; CD: Crobn's disease

Incorrect( *): inconclusive or incorrect in relation with gold standard.

TABLE 6 - Quality indices and their estimated 95\% interval of confidence obtained from OD and RSD

\begin{tabular}{lcccc}
\hline \multirow{2}{*}{ Quality indices } & \multicolumn{2}{c}{ OD (\%) } & \multicolumn{2}{c}{ RSD (\%) } \\
\cline { 2 - 5 } & UC & CD & UC & CD \\
\hline Sensibility & 100 & 85.7 & 100 & 92.3 \\
& & $(59.8,100)$ & & $(77.8,100)$ \\
Specificity & 85.7 & & 92.3 & 100 \\
Positive & $(59.8,100)$ & 100 & $(77.8,100)$ & \\
predictive value & $(89.2,100)$ & 100 & 96.7 & 100 \\
Negative & 100 & 96.3 & $(90.2,100)$ & \\
predictive value & & $(89.2,100)$ & 100 & 96.7 \\
& 97.0 & 97.0 & 97,6 & 97.6 \\
Accuracy & $(91.1,100)$ & $(91.1,100)$ & $(93.0,100)$ & $(93.0,100)$ \\
\hline
\end{tabular}

OD: original diagnosis; RSD: reviewed standardized diagnosis; UC: ulcerative colitis; CD: Crohn's disease.

\section{DISCUSSION}

Inconclusive diagnoses such as "chronic inflammation" and "nonspecific inflammation" are of limited value for both the physician and the pathologist ${ }^{(11,28)}$, and despite the clinicopathological correlation be the goal of histopathology, it is not always possible because the information is not available, or clinical data provided contradict the histopathological findings. In these cases, the pathologist needs to extract as much information as possible from the biopsy. For an appropriate evaluation of biopsy in IBD, the pathologist should be informed about the duration of symptoms and what kind of treatment was given to the patient because the treatment can produce patchiness or discontinuity of mucosal inflammation in UC making a differential diagnosis more difficult ${ }^{(10)}$. Another study refers that the treatment of UC can lead to partial cure, which results in focal lesions simulating distribution of $\mathrm{CD}^{(29)}$. This fact has already been reported ${ }^{(14)}$ highlighting the focal distribution of the lesions in the UC treated. The treatment can produce a variety of changes including normalization of the mucosa. Some authors emphasize that the 
information about therapeutics should be given to the pathologist avoid misdiagnosis ${ }^{(17,18,27)}$. Other authors state that only the epithelioid granulomas without ruptured crypts and or chronic active ileitis are features highly suggestive of $\mathrm{CD}$ on mucosal biopsy analysis and that some UC exams may show discontinuous disease, no rectal disease, inflammation in ileum, extracolonic involvement, granulomatous inflammation, aphthous ulcers or mural inflammation. In these cases, the differential diagnose with CD can be almost impossible ${ }^{(30)}$. In the appropriate clinical presentation the presence of granuloma inflammation in gastrointestinal biopsy specimens confirms the diagnosis of $\mathrm{CD}^{(16,32)}$, and when the granuloma is not found, the diagnoses of CD should be suggested emphasizing the necessity of correlation with others clinical, endoscopic and imaging features ${ }^{(9)}$. In a study the evaluation of mucosal biopsy in patients with $\mathrm{CD}$ demonstrated increased numbers of macrophages and microgranulomas with the help of the technique of immunohistochemistry for $\mathrm{CD}_{68}+{ }^{(31)}$. Another difficulty is the presence of granulomas related with crypts ruptures. To distinguish between epithelioid granuloma and a granulomatous lesion by rupture of crypt, cuts in multiple tissue levels may be necessary to find the presence of neutrophils, lymphocytes, and foamy macrophages that are absents in the former ${ }^{(30)}$.

In the present study, the histopathological diagnosis was correct and conclusive in OD at $74.4 \%$ of patients, and in $97.7 \%$ RSD, demonstrating that the last one increased correlation with the gold standard for diagnosis. This percentage was also higher than those found by several studies ${ }^{(6,15,20,21,27,28)}$ in which the correlation was $94 \%, 80 \%, 75 \%, 72 \%, 73 \%$, and $73 \%$ respectively. Our hypothesis that the standardized histopathological diagnosis increases the correlation with the gold standard in IBD was supported on two other studies ${ }^{(3,13)}$. There is several studies on determining the histopathological criteria more discriminately, and on how better applying them to the diagnosis of IBD. In some studies, the criteria are repeated, consolidating its importance in the diagnosis of IBD, as occurred, for example, with the alteration in cryptic architecture, which is present in seven reviewed studies $(6,13,15,21,23,24,27)$. The authors of the study that was used as a model for the standardization review of cases evaluated ${ }^{(24)}$ observed that basal plasmacytosis (Figure 1) associated with severe inflammatory infiltrate is more discriminative than plasmocytosis considered individually. They also observed that the diffuse crypt atrophy (Figure 2B) is characteristic of UC, whereas segmental atrophy is related with $\mathrm{CD}$. Figure $\mathbf{2 A}$ shows a comparison between a normal mucosa and a mucosa with crypt atrophy. However, they did not consider cryptic abscesses and cryptitis discriminative for the differential diagnosis between

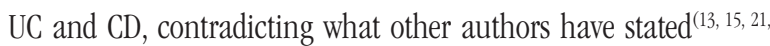

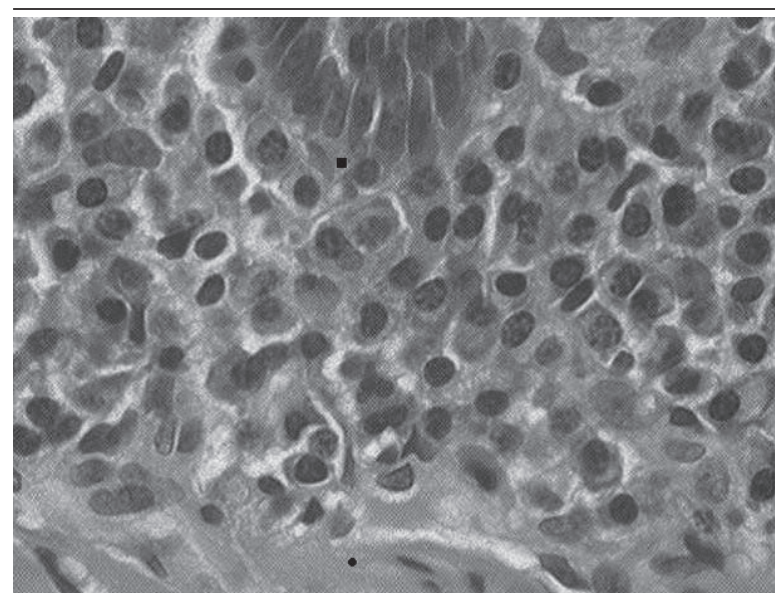

FIGURE 1 -Basal plasmacytosis: presence of numerous plasma cells between the crypt base (-) and muscularis mucosa ( $\mathbf{0}$ ) (HE, lens 400×)

HE: hematoxylin-eosin.

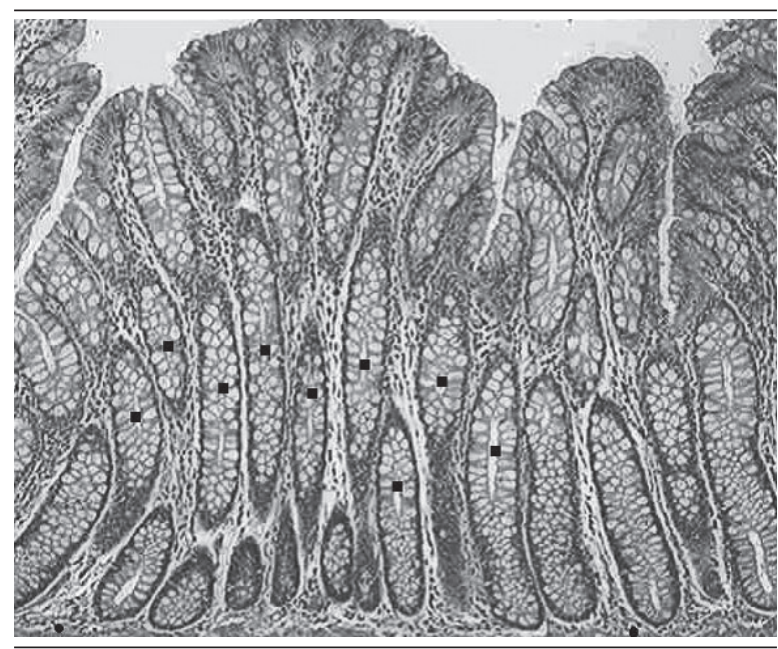

FIGURE 2A - Normal colonic mucosa with crypts ( $\mathbf{0}$ ) tubular, parallel, straight, and juxtaposed to the muscularis mucosa (- (HE, lens 40×) HE: bematoxylin-eosin.

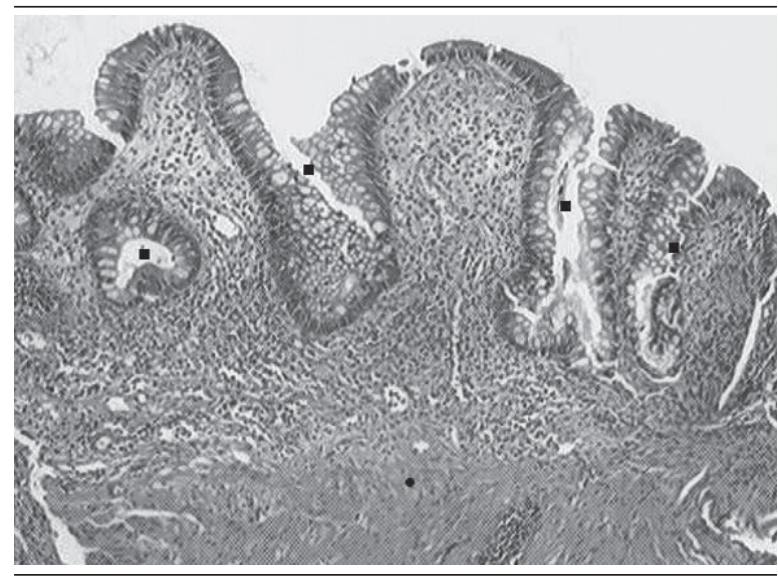

FIGURE 2B - Crypt atrophy characterized by tortuosity, scarcity and shortening of the crypts ( $)$ which basis is far from muscularis mucosa ( $(H E$, lens $40 \times$ ) HE: hematoxylin-eosin. 
27, 28). Paneth metaplasia (Figure 3) was not analyzed in some studies ${ }^{(13,20,21)}$, but was analyzed and considered important in six other studies ${ }^{(6,24-28)}$. In the studies reviewed, the histopathological findings were evaluated taking into account different criteria. The study we have chosen as model for standardized review, assessed 70 criteria (the largest number of criteria among the studies reviewed), which were tested and selected by statistical calculations ${ }^{(24)}$. The series of three studies of these authors ${ }^{(24-26)}$ consisted of 431, 726, and 60 cases respectively. Together, it is the largest study that used the same criteria for IBD biopsies histopathological evaluation. In the present study, only one case of CD (number 25 in Table 3) was diagnosed as UC by RSD. In this case, we observed that rectal mucosa was compromised, there was diffuse distribution of atrophy and crypt distortion (Figure 4) (criterion H5), segmental distribution of mucin depletion (criterion H6) and preservation of

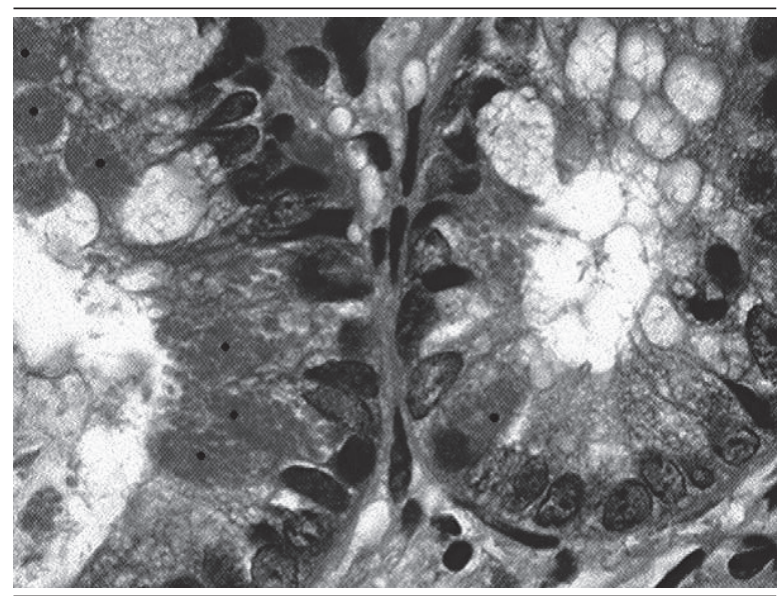

FIGURE 3 - Paneth cell metaplasia: presence of Paneth cells ( ) lined crypts in samples after colon right angle (HE, lens 400×)

HE: hematoxylin-eosin.

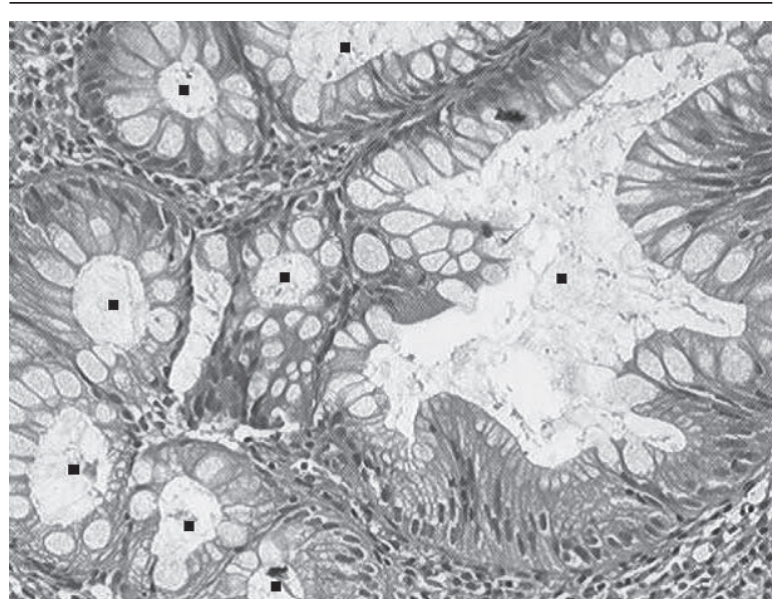

FIGURE 4 - Crypt distortion: branching, dilatation, and tortuous crypts (HE, lens $100 \times$ )

HE: bematoxylin-eosin. mucin in areas of acute inflammation (criterion $\mathrm{H7}$ ). A conflict was observed in the histopathological criteria in this case: the diffuse and continuous distribution of cryptic changes from the rectum is characteristic of UC according to some authors observations ${ }^{(23,24)}$. Another unusual feature found in this $\mathrm{CD}$ case was the commitment of the rectum, which is usually spared in $\mathrm{CD}^{(12)}$. The case inconclusive by RSD (number 34 in Table 3) was defined by the gold standard as UC, but it presented: segmental distribution of crypt architectural changes (criterion H5), segmental distribution of depletion of mucus (criterion $\mathrm{H} 6$ ), and focal inflammation, which are histopathological characteristics of $\mathrm{CD}^{(23,24)}$. On this exam request there was no information about the patient being in treatment at the time of biopsies, even though it has endoscopic appearance of UC, but with segmental distribution. In biopsies of children with UC, architectural distortion of crypts occurs in $32.1 \%$, while it happens in $57.9 \%$ of adults ${ }^{(2)}$. The authors correlate this difference with the shorter duration of disease before biopsy in pediatric cases. There is a contradiction between the observations of some studies ${ }^{(23,29)}$ about the time for the appearance of architectural changes promoted by IBD. A study argues ${ }^{(23)}$ that they are precocious and can be detected in biopsies from patients with seven days of onset of disease activity, and moreover the architectural changes are the most important in the diagnosis of IBD histopathology, once it differ in each type of IBD: diffuse for UC, and focal for CD. These authors also note that these changes are not exclusive to IBD as they can be found in intestinal amebiasis and shigellosis cases, depending on the strain and duration of infection (greater than one week). The quality scores obtained by OD and RSD in the present research were not consistent with one study ${ }^{(4)}$. Here RSD presented specificity, positive predictive value, and accuracy for UC slightly larger than OD. RSD also showed sensitivity, negative predictive value, and accuracy for $\mathrm{CD}$ slightly larger than $\mathrm{OD}$. In conclusive cases the specificity for UC and sensitivity to CD (both 92.3\%) were higher in RSD than in OD (both 85.7\%), agreeing with the results of several studies ${ }^{(1,3,13,24-27)}$ that consider the standardization of histopathological criteria a necessary instrument for improving the quality indices of histopathological diagnosis

\section{CONCLUSION}

RSD diagnosis had a higher percentage of correct and conclusive diagnoses than those presented in OD, especially statistically significant difference for CD exams. RSD's conclusive cases obtained slightly higher specificity rates, positive predictive value, and accuracy for UC; slightly higher sensitivity rates, negative predictive value, and accuracy for $\mathrm{CD}$, when compared to $\mathrm{OD}$. 


\section{RESUMO}

Introdução: Duas são as formas de manifestação da doença intestinal inflamatória: doença de Crobn e retocolite ulcerativa, ambas com evolução clinica, tratamento e aspectos histopatológicos diferentes, causando, por vezes, significativa morbidade. Objetivos: Escolher e aplicar método padronizado e quantificado de diagnóstico histopatológico e comparar os resultados e os indices de qualidade, com os dos diagnósticos originais. Materiais e métodos: Foram reavaliadas histologicamente 43 biópsias colonoscópicas seriadas de 37 pacientes por sistema padronizado. Resultado e discussão: Os diagnósticos originais foram mais inconclusivos (23,3\%) do que os padronizados (2,3\%). A concordância com o padrão-ouro (diagnóstico clínico, colonoscópico e radiológico) foi maior nos diagnósticos padronizados (95,3\%) do que nos originais (74,4\%), principalmente em relação à doença de Crohn, cujospercentuais foram de 92,3\% e 46,1\%, respectivamente. Para retocolite ulcerativa, ambos os métodos apresentaram sensibilidade e valor preditivo negativo de 100\%; já nos diagnósticos originais, foram verificados especificidade de 85,7\%, valor preditivo positivo de 96,3\% e acurácia de 97\%, e nos diagnósticos padronizados, 92,3\%, 96,7\% e 97,6\%, respectivamente. Para doença de Crobn, verificaram-se especificidade e valor preditivo positivo de 100\% nos dois métodos; nos diagnósticos originais, sensibilidade de 85,7\%, valor preditivo negativo de 96,3\% e acurácia de 97\%, e nos diagnósticos padronizados, 92,3\%, 96,7\% e 97,6\%, respectivamente. Conclusão: O diagnóstico padronizado apresentou maior percentual de diagnósticos corretos e conclusivos do que os apresentados no diagnóstico original, principalmentepara doença de Crobn, assim como valores iguais ou ligeiramente maiores em alguns indices de qualidade.

Unitermos: retocolite ulcerativa; doença de Crobn; biópsia; patologia.

\section{REFERENCES}

1. ALVES, P. R. A. et al. Histological scores on the colonoscopic diagnosis of inflammatory bowel disease. Arq Bras Cir Dig, v. 9, p. 67-70, 1994.

2. BANCROFT, J. D.; STEVENS, A. Theory and practice of histological techniques. New York, NY: Churchill Livingstone, 1977.

3. BENTLEY, E. et al. How could improve the initial diagnosis of colitis? Evidence from an international workshop. J Clin Pathol, v. 55, p. 955- 60, 2002.

4. CROSS, S.S.; HARRISON, R. F. Discriminant histological features in the diagnosis of idiopathic inflammatory bowel disease: analyses of a large dateset by novel data visualization technique.J Clin Pathol, v. 55, p. 51-7, 2002.

5. DANI, R. Gastroenterologia essencial. Rio de Janeiro, RJ: Guanabara Koogan, 2011.

6. DUNDAS, S. A. C.; DUTTON, J.; SKIPWORTH, P. Reliability of rectal biopsy in distinguishing between chronic inflammatory bowel disease and acute self-limiting colitis. Histopathol, Oxford, v. 31, p. 60-6, 1997.

7. EKBOM, A. et al. Increase risk of large-bowel cancer in Crohn disease with colonic involvement. Lancet, London, v. 336, p. 357-9, 1990.

8. FARMER, M. et al. The importance of diagnostic accuracy in colonic inflammatory bowel disease. Am J Gastroenterol, New York, v. 95, n. 11, p. 3184-8, 2000.

9. GARETH, P. J.; RAVIKUMARA, M. Endoscopic and histologic findings in pediatric inflammatory bowel disease. Gastroenterol Hepatol, v. 6, p. $174-80,2010$
10. GEBOES, K. Pathology of inflammatory bowel diseases (IBD): variability with time and treatment. Col Dis, v. 3, p. 2-12, 2001.

11. GEBOES, K.; EYKEN, P. V. Inflammatory bowel disease unclassified and indeterminate colitis: the role of the pathologist.J Clin Pathol, v. 62 , p. 201-5, 2009.

12. HARRISON, T. R. Harrison's principles of internal medicine. New York, NY: McGraw-Hill, 2011.

13. JENCKINS, B. et al. Guidelines for the initial biopsy diagnosis of suspected chronic idiopathic inflammatory bowel disease: the British Society of Gastroenterology iniciative.J Clin Pathol, v. 50, p. 93-105, 1997.

14. KIM, B. et al. Endoscopic and histological patchiness in treated ulcerative colitis. Am J Gastroenterol, v. 94, p. 3258-62, 1999.

15. LE BERRE, N. et al. Histological discrimination of idiopathic inflammatory bowel disease from others types of colitis. J Clin Pathol, v. 48, p. 749-53, 1995.

16. LUDEMAN, L.; SHEPHERD, N. A. Problem areas in the pathology of chronic inflammatory bowel disease. Cur Diag Pathol, v. 12, p. 248-60, 2006.

17. MAGR0, F. et al. European consensus on the histopathology of inflammatory bowel disease.J Crohns Colitis, v. 7, p. 827-51, 2013.

18. MATTEO, C. et al. Chronic idiopathic inflammatory bowel diseases: the histology report. Digest Liver Dis, v. 43S, p. S293-S303, 2011.

19. MICHALANY, J. Técnica bistológica em anatomia patológica: com instruções para o cirurgião, enfermeira e citotécnico. São Paulo, SP. Editora Pedagógica Universitária, 1980.

20. SCHMITZ-MOORMANN, P.; HIMMELMANN, G. W. Does quantitative histology of rectal biopsy improve the differential diagnosis of Crohn's 
disease and ulcerative colitis in adults? Pathol Res Pract, v.183, p. 481-8, 1988 .

21. SELDENRIJK, C. A. et al. Histopathological evaluation of colonic mucosal biopsy specimens in chronic inflammatory bowel disease: diagnostic implications. Gut, v. 32, p. 1514-20, 1991.

22. SPENCER, M. Fundamentals of light microscopy. Cambridge: University Press, 1982.

23. SURAWICZ, C. M. et al. Mucosal biopsy diagnosis of colitis: acute selflimited colitis and idiopathic inflammatory bowel disease. Gastroenterol, v. 107 , p. $755-63,1994$.

24. TANAKA, M. et al. Morphologic criteria applicable to biopsy specimens for effective distinction of inflammatory bowel disease from others forms of colitis and of Crohn disease from ulcerative colitis. Scand J Gastroenterol, v. 34, p. 55-67, 1999.

25. TANAKA, M. et al. Simple mucosal biopsy criteria differentiating among Crohn's disease, ulcerative colitis, and other forms of colitis: measurement of validity. Scand J Gastroenterol, v. 35, p. 281-6, 2000.
26. TANAKA, M. et al. Observer variation of diagnoses based on simple biopsy criteria differentiating among Crohn's disease, ulcerative colitis, and other forms of colitis. J Gastroenterol Hepatol, v. 16, p. 1368-72, 2001.

27. THEODOSSI, A. et al. Observer variation and discriminatory value of biopsy features in inflammatory bowel disease. Gut, v. 35, p. 961-8, 1994. 28. TSANG, P.; ROTTERDAM, H. Biopsy diagnosis of colitis: possibilities and pitfalls. Am J Surg Pathol, v. 23, p. 423-30, 1999.

29. WASHINGTON, K. et al. Histopathology of ulcerative colitis in initial rectal biopsy in children. Am J Surg Pathol, v. 26, p. 1441-9, 2002.

30. YANTISS, R. K.; ODZE, R. D. Diagnostic difficulties in inflammatory bowel disease pathology. Histopathol, v. 48, p. 116-32, 2006.

31. YANTISS, R. K. et al. Increased CD68 positive macrophages and macrophage microaggregates are prevalent in Crohn's colitis and aid in its distinction from ulcerative colitis. Mod Pathol, v. 18, p.123A, 2005.

32. TAKASHI, H. et al. Evaluation of diagnostic criteria for Crohn's disease in Japan.J Gastroenterol, v. 49, p. 93-9, 2014.

\section{MAILING ADDRESS}

Rosimeri Kuhl Svoboda Baldin

Rua General Carneiro, 181; Centro; CEP: 80060-900; Curitiba-PR, Brazil; Phone: +55 (41) 3360-1813; Fax: +55 (41) 3524-0035; Celular: +55 (41) 8425-7284; e-mail: ksbaldin@ig.com.br. 